\title{
POEMS: A TOOL FOR AMALGAMATING CHEMISTRY WITH ARTS FOR EFFECTIVE LEARNING
}

\author{
Dr. Prathima Mathias D A \\ Assistant Professor, Department of Chemistry, I D S G Government College, \\ Chikkamagaluru, Karnataka, India \\ Email: prathimamathias@gmial.com
}

\begin{abstract}
Teaching different branches of chemistry in class room is a Herculean task. Students with various backgrounds and mindsets are the biggest challenge every chemistry teacher faces. An integrated method of teaching like: talk and chalk, audio visuals, quizzes, puzzles, riddles, cartoons and poetry, improves learning abilities and covers wide band of student learners. At degree and post graduate levels, various emotional changes occurring in tender minds. By framing relevant poems, these emotions can be effectively utilized and channelized towards learning chemistry. A safer method is use clichés as currencies to barter knowledge in chemistry. Combination of arts with chemistry can spark up learning in young minds, leading to long term memory stamping. This paper presents few poems that correlate chemistry with emotions.
\end{abstract}

Key words: Arts, Chemistry, Psychomotor learning, Poems.

Cite this Article: Dr. Prathima Mathias D A, Poems: A Tool for Amalgamating Chemistry with Arts for Effective Learning. International Journal of Intellectual Property Rights, 10(2), 2019, pp. 10-14. http://iaeme.com/Home/issue/IJIPR?Volume=10\&Issue=2

\section{INTRODUCTION}

Many Indian universities providing three year degree in science courses have language papers in first four semesters, which are excluded in fifth and sixth semesters. These subjects are not considered for ranking criteria. Science students therefore, have a general mindset of neglecting language classes and concentrating only on science subjects. This trend has led to failure in expressing views and opinions of scientific lot. When they adopt career in teaching or research, delivering a simple topic in any particular language gets dearer. Lack in language presentation skills results in sharp increase in rate of plagiarism. Teaching chemistry without language is unimaginable. To imbibe classroom lectures on analytical, Inorganic, organic or physical chemistry, a student requires imaginary skills. A chemistry teacher needs to combine visual, aural, verbal, logical, social and solitary methods to deliver an effective lecture. Aural and verbal methods of communication are a must in teaching. Government initiatives to provide smart class rooms under RUSA funding have to some extent helped in visual 
learning. Unfortunately our college, has only two such classrooms for science with greater than 900 student strength, thereby limiting its utilizing capacity. In absence of visual methods a teacher can resort to adding logical and social methods of imparting knowledge. Activities like quizzes, puzzles, anecdotes and riddles help in learning ${ }^{1}$. Therefore these can be framed by the instructor and used as need be. Uses of drama/movies in learning have been adopted at various places, ${ }^{2-5}$ showing us that books are not the ultimate source of learning. This method enhances psychomotor skills and lays a huge impact on receptivity of brain. Alternatively, competitions can be organized among students to bring out new ideas of their own. A poetic teacher can further enrich the classroom learning, because there is no soul that detests songs. Dr. Sukarma Rani after completing her lectures has been encouraging her students to summarize their learning in the form of poems ${ }^{6}$. Araujo et al. ${ }^{7}$ experimented use of poetry and cartoons in learning about alkali metals. Their questionnaire survey voted highly for such strategy which improved constructive learning. Audrey et al. creatively incorporated poetry in mineralogy. Students commented that using poems made them not only understand but become more passionate about getting a job of as mineralogist ${ }^{8}$. Joao et al. in their research summarize importance of promoting socio-historical understanding for inculcating scientific literacy skills to meet requirements of modern world ${ }^{9}$. Innovative research in educating chemistry can be increased by coupling fine art work with poetry. Such methods help chemistry come alive on campus and provide aesthetic appeal ${ }^{10}$. Utilizing human emotions and their correlation to learn a subject leaves non erasable memory. This is the scope of the present paper.

\section{METHODOLOGY}

Present paper focuses on improving curricular learning through poems. These poems use clichéd emotions and appropriate photographs to convey the message effectively. Few illustrative poems are given in Table-1. Sample photographs Figure 1 to 3 are provided alongside to help imagination.

Table 1 Poems with learning outcome

\begin{tabular}{|c|c|c|c|}
\hline No. & Title & Poem & $\begin{array}{c}\text { Learning } \\
\text { outcome }\end{array}$ \\
\hline 1 & Adhesion & I am unique and unlike you, \\
& & Cohesively form no bond. & Adhesion, \\
& & Unknowingly, Adhesively, & Blindly we share this song. \\
Cohesion and \\
their relation \\
with gravity. \\
Nature of \\
\end{tabular}




\begin{tabular}{|c|c|c|c|}
\hline & & $\begin{array}{l}\text { My soul merges in you. } \\
\text { I am all electrons, } \\
\text { Now colored with blue. } \\
\text { Bring forth those unsaturation's, } \\
\text { I will reduce you. } \\
\text { I boom with fire on water, } \\
\text { Separated from you. } \\
\text { Come let us redox together. }\end{array}$ & $\begin{array}{c}\text { sodium form } \\
\text { blue colored } \\
\text { strongly reducing } \\
\text { solution }\end{array}$ \\
\hline 4 & Autograph & $\begin{array}{c}\text { Your autograph on my heart, } \\
\text { Tattooed indelibly. } \\
\text { Thousands may come, } \\
\text { And a thousand may go. } \\
\text { Nothing matters me. }\end{array}$ & $\begin{array}{l}\text { Longevity of } \\
\text { indelible ink } \\
\text { used in tattoos }\end{array}$ \\
\hline 5 & Bonding & $\begin{array}{l}\text { It requires orbitals to be vacant, } \\
\text { And energies to be spent. } \\
\text { Bringing two dissimilar atoms together, } \\
\text { Happens, when stability it attains. } \\
\text { If you aren't empty, } \\
\text { Bonding hardly occurs. } \\
\text { Thirst to be filled, } \\
\text { Since big boom drives this universe. } \\
\text { Noble like gold? Go on! } \\
\text { Else bind like cyanide to iron. }\end{array}$ & $\begin{array}{c}\text { Bonding is } \\
\text { driven by force } \\
\text { to attain stability. } \\
\text { Difference } \\
\text { between strong } \\
\text { and weak bonds. }\end{array}$ \\
\hline 6 & Distilling life & $\begin{array}{l}\text { Life heats, boils and } \\
\text { Gives you no option. } \\
\text { That's when you distill as pure solvent } \\
\text { And not a solution. } \\
\text { I have done my boiling, } \\
\text { am not azeotropic, } \\
\text { Don't get me wrong, } \\
\text { I'm not universal. } \\
\text { I'm done with solutes, } \\
\text { No more solutioning. }\end{array}$ & $\begin{array}{c}\text { Azeotropic } \\
\text { mixtures, } \\
\text { universal solvent } \\
\text { and distillation } \\
\text { criteria. }\end{array}$ \\
\hline 7 & Recry & $\begin{array}{c}\text { Many people I daily meet, } \\
\text { Few I teach and others me teach. } \\
\text { With age experience saturate, } \\
\text { Emerging crystals rare and great. } \\
\text { Very dilute solutions/relations nothing does } \\
\text { hold, } \\
\text { Fight for heart's nude connections, } \\
\text { With no void spaces or defects untold. }\end{array}$ & $\begin{array}{l}\text { Criteria for } \\
\text { recrystallization } \\
\text { and possible } \\
\text { defects in } \\
\text { crystals. }\end{array}$ \\
\hline & $\begin{array}{l}\text { Figure 2: Flak with } \\
\text { crystals }\end{array}$ & & \\
\hline
\end{tabular}




\begin{tabular}{|c|c|c|c|}
\hline 8 & $\begin{array}{c}\text { Few welcome me with prisms, } \\
\text { I disperse to colour their lives. } \\
\text { Few more bend and refract me, } \\
\text { Suiting their medium to rejoice. } \\
\text { Some have sharp edges and grate me, } \\
\text { Molding me as per choice. } \\
\text { In dark few sit and absorb me, wise? } \\
\text { There are a few, who bounce me, } \\
\text { Reflecting all I give. }\end{array}$ & $\begin{array}{c}\text { Properties of } \\
\text { electromagnetic } \\
\text { radiation and its } \\
\text { interaction with } \\
\text { matter. }\end{array}$ \\
Figure 3: lamp & $\begin{array}{c}\text { I disperse, refract monochromate and get } \\
\text { absorbed. }\end{array}$ & \\
& Alas! When reflection is all I see, \\
& Slowly pack up, retrace my path. \\
Console my heart and say, & \\
& You are too polished and slippery, \\
& I am wild, untamed, \\
& You don't deserve me. & \\
& \\
&
\end{tabular}

\section{SCOPE AND CONCLUSION}

On combining Arts with a difficult subject like chemistry, understanding level increases. It can however be improved by involving students to write small projects with crosswords and cartoons. Only drawback in these poems is that, a non -science student may find grasping them impossible. A survey after implementing such an activity can boost the effectiveness of such methods in Graduate and Post Graduate studies.

\section{REFERENCES}

[1] Teaching chemical technique. A review of the literature, Stephen Demeo, Journal of Chemical Education, 78(3), March 2001, PP 373-379.

[2] Books, Movies and Chemistry, Retrieved on 10/12/2019, https://WWW.acs.org/content/acs/en/education/students/highschool/chemistryclubs/activit ies/chemitry-books-movies.html

[3] Kerstin Danckwardt-Lilliestrom, Maria Andree, Margareta Enghag, Creative drama in chemistry education: a social semiotic approach, Nordic Studies in Science Education, 14(3), 2018, PP 250-266.

[4] Kirk Dorion, Dissertation thesis 'An exploration of how a drama-based pedagogy can promote understanding of chemical concepts in 11-15 year old science students, University of Cambridge, March 2007.

[5] Stefanos Karageorgiou, Eirini Savvidou, Parthena Kathikaridou, Percles D Akrivos, Hector Katsikis, A chemistry teacher's drama in the Greek high school with biology as the protagonist, Journal of International Scientific Publications, 13, 2015, PP 395-403.

[6] Teaching science through poetry in India, retrieved on 10/12/2019

https://www.sawtrust.org/worldwide/science-through-poetry-in-india/ 
Poems: A Tool for Amalgamating Chemistry with Arts for Effective Learning

[7] J.L.Araujo, C.Morias and J.C. Palca, Poetry and alkali metals: building bridges to the study of atomic radius and ionization energy, Chemistry Education Research and Practice, Chemical Educational Research Practices, 16, 2015, PP 893-900.

[8] Audrey C. Rule, Luke A. Camicelli, Sharon S. Kane, Using poetry to teach about minerals in Earth science class, Journal of Geoscience Education, 52(1), 2004, 10-14.

[9] Joao Carlos Palva, Carla Morais, Specialization, chemistry and poetry: challenging chemistry boundaries, Journal of Chemical Education, 90(12), 2013, PP 1577-1579.

[10] Ping Y. Furlan, Herbert Kitson and Cynthis Andes, Chemistry, poetry and artistic illustration: An interdisciplinary approach to teaching and promoting chemistry, Journal of Chemical Education, 84(10) 2007, PP 1625. 